\title{
ETHYLENE POLYMERIZATION WITH NICKEL DIIMINE COMPLEXES CONTAINING PSEUDOHALIDES
}

\author{
Marcos L. Dias ${ }^{\mathrm{a}, *}$, Luciana P. Silva ${ }^{\mathrm{b}}$, Geraldo L. Crossettic ${ }^{\mathrm{and}}$ Carlos A. L. Filgueiras ${ }^{\mathrm{d}}$ \\ anstituto de Macromoléculas Professora Eloisa Mano, Universidade Federal do Rio de Janeiro, Av. Horácio Macedo, 2030, 21941 - \\ 598 - Rio de Janeiro - RJ, Brasil \\ ${ }^{b}$ Instituto Nacional da Propriedade Industrial - INPI, Rua Mayrink Veiga, $n^{\circ}$ 9, $10^{\circ}$ andar, Centro, 20090-910 Rio de Janeiro - RJ, Brasil \\ 'Universidade Federal do Pampa, Campus Itaqui, Rua Luiz Joaquim de Sá Britto, s/n, 97650-000 Itaqui - RS, Brasil \\ dDepartamento de Química, Universidade Federal de Minas Gerais, Belo Horizonte - MG, Brasil
}

Recebido em 08/01/2018; aceito em 16/09/2018; publicado na web em 22/05/2018

\begin{abstract}
Nickel-diimine complexes DADNiX $\left(\mathrm{DAD}=2,6-\mathrm{Pr}_{2}-\mathrm{C}_{6} \mathrm{H}_{3}-\mathrm{N}=\mathrm{C}(\mathrm{Me})-\mathrm{C}(\mathrm{Me})=\mathrm{N}-2,6-\mathrm{Pr}_{2}-\mathrm{C}_{6} \mathrm{H}_{3}\right)$ containing the non-chelating pseudohalide ligands isothyocyanate and isoseleniumcyanate (X= NCS 1 and NCSe 2) were synthesized and used in ethylene polymerization activated by methyaluminoxane (MAO) at temperatures from 0 to $50^{\circ} \mathrm{C}$. Polymerizations with these complexes were compared with the analogous Ni-diimines halide $(\mathrm{X}=\mathrm{Br} \mathbf{3})$ as non-chelating ligand. All systems were very active in this polymerization. The increase of reaction temperature favored the increase in catalytic activity. The catalyst system 1/MAO was more stable than the others, showing the best catalytic activity at the molar ratio Al/Ni between 200 and 300. System 2/MAO showed to be the less stable and less active, particularly at $50^{\circ} \mathrm{C}$. Polyethylenes obtained with systems $\mathbf{1}, \mathbf{2}$ and $\mathbf{3}$ show high molecular weights, are branched polymers, and predominately amorphous, but the majority still present DSC endothermal events related to melting of small crystals. When halide $(\mathrm{Br})$ are compared with these pseudo-halides, different activities, polymerization kinetics and characteristics of the final polymer indicated modification in the active species caused by the non-chelating ligand. Polymer molecular weight and branching content was not significantly influenced by the non-chelating ligand, being much more dependent on the MAO/Ni molar ratio and polymerization temperature.
\end{abstract}

Keywords: ethylene polymerization; pseudo-halide ligands; Ni-diimine complexes; isothiocyanate; isoseleniumcyanate; branched polyethylenes.

\section{INTRODUCTION}

Polymerization of olefins with metal catalyst complexes has been a topic of significant interest. Since the discovery that palladium and nickel-diimine complexes are capable of polymerizing ethylene to high molecular weight branched polyethylenes, efforts have been made to discover ligands to be used in new complexes and to understand the mechanisms and factors controlling polymer formation and microstructure by using these complexes as catalysts. ${ }^{1-10}$ Catalyst activity as well as branching number, distribution of branch type and molecular weight of polyethylenes obtained with Ni catalyst systems seem to be determined mainly by the type of $\mathrm{Ni}$ chelating ligand, but are also markedly influenced by the polymerization conditions, including the cocatalyst type. ${ }^{11-15}$ There is much work about the influence of the diimine structure on the polymerization of olefins, but few are related to the influence of the non-chelating ligands in these complexes. ${ }^{16-19}$ The accepted mechanism for late transition metal-catalyzed polymerization involves a cationic organometallic species. ${ }^{20}$ Thus, in the case of reactions cocatalyzed by alkylaluminum compounds the counter ion of the active species produced from the interaction of the non-chelating ligand (usually a halide), with the alkyl aluminum activator may also play an important role in the polymerization. ${ }^{21,22}$ Nevertheless, the influence of the non-chelating ligand on the polymerization of olefins with $\mathrm{Ni}$ complexes has received less attention.

Although literature have reported large number of papers on olefin polymerization with $\mathrm{Ni}$ diimines containing the true halides $\mathrm{Cl}$ and $\mathrm{Br}$ as non-chelating ligands, no report was found about the effect of different pseudohalides on ethylene polymerization catalyzed by $\mathrm{Ni}$ diimine complexes containing this type of framework. Pseudohalides

*e-mail: mldias@ima.ufrj.br are defined as polyatomic anions with features bearing some resemblance to true halides $\left(\mathrm{F}^{-}, \mathrm{Cl}^{-}, \mathrm{Br}^{-}\right.$and $\left.\mathrm{I}^{-}\right)$, generally with same types of chemistry and similar mechanisms. ${ }^{23,24}$

Few works have been reported on the synthesis of Ni diimine complexes containing pseudo-halides. ${ }^{25,26}$ Nevertheless, these complexes can give rise to interesting catalysts. Among several classes of pseudohalides, cyanates are one of interest due to the facility in the synthesis of diimine metal complexes. For instance, the synthesis of diimine metal-thiocyanates (NCS) complexes and their spectroscopic investigations have been reported by some authors. ${ }^{25-27 \text { NCS }}$ groups can be linked to the metal by the sulfur atom (thiocyanate, $\mathrm{N} \equiv \mathrm{C}-\mathrm{S}^{-}$) or by the nitrogen atom (isothiocyanate, $\mathrm{N}=\mathrm{C}=\mathrm{S}$ ).

We have reported previously our studies on homo- and copolymerization of ethylene, propylene and hexene using nickel diphosphine and diimine complexes containing isothiocyanate as non-chelating ligand. ${ }^{28-31}$ When activated by methylaluminoxane (MAO), these complexes showed good activity, producing polymers with different microstructure, but these $\mathrm{Ni}$ diimine complexes can be also activated by using others alkyl aluminum as a cocatalyst, like ethylaluminum sesquichloride (EASC). ${ }^{32}$

In this paper we discuss the effect of the pseudo-halides isothiocyanate and isoseleniumcyanate (NCSe) on the polymerization of ethylene with methylaluminoxane (MAO) as cocatalyst, comparing their performance with that of the bromide analogous halide.

\section{EXPERIMENTAL}

\section{Materials}

The reactions were performed using standard Schlenk techniques. Nitrogen, argon and ethylene were purified by passing them through 
columns of $3 \AA$ molecular sieves and copper catalyst. Toluene was distilled with sodium and benzophenone under nitrogen. $\mathrm{CH}_{2} \mathrm{Cl}_{2}$ and $\mathrm{MeCN}$ were dried with $\mathrm{CaH}_{2}$, distilled and used immediately. MAO (Witco) was purchased as a $10 \%$ toluene solution. $88 \%$ formic acid (Vetec), 97\% 2,3-butanedione (Aldrich) and 90\% 2,6-diisopropylaniline (Aldrich) were used as received.

\section{Synthesis of Ni-diimine complex}

The nickel diimine complexes $\mathrm{DADNiX}_{2} \mathbf{1}, \mathbf{2}$ and $\mathbf{3}$ (DAD=2,6${ }_{i P r}-\mathrm{C}_{6} \mathrm{H}_{3}-\mathrm{N}=\mathrm{C}(\mathrm{Me})-\mathrm{C}(\mathrm{Me})=\mathrm{N}-\mathrm{C}_{6} \mathrm{H}_{3}-2,6-\mathrm{Prr}_{2} ; \mathrm{X}=\mathrm{NCS} \mathbf{1}, \mathrm{NCSe} 2$ and $\mathrm{Br} 3$ (Figure 1) were synthesized according procedures previously reported. . $^{29,30}$

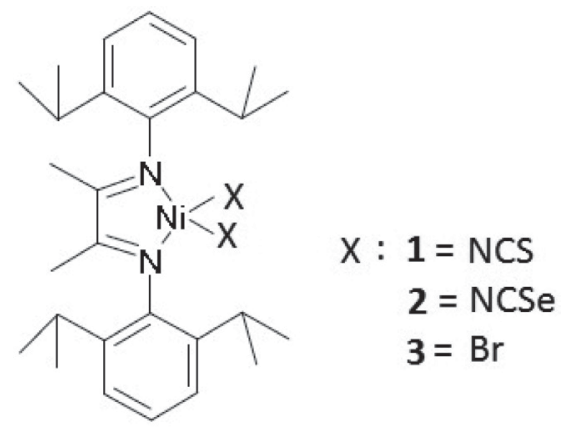

Figure 1. Structure of the complexes 1, 2 and $\mathbf{3}$

\section{Polymerization}

Polymerizations were performed in a previously dried and nitrogen flushed $250 \mathrm{~mL}$ Büchi glass autoclave coupled with an in line Brooks flowmeter. The reactor temperature was adjusted by a thermostatic bath. Toluene and a measured amount of MAO were charged into the reactor. Nitrogen was replaced by ethylene and the reactor saturated with the monomer under pressure. After saturation, a fresh catalyst solution was charged into the reactor under pressure, starting the polymerization. The reactions were terminated after $1 \mathrm{~h}$ by quenching the mixture with a dilute $\mathrm{HCl}$-ethanol solution. The polymers were precipitated in ethanol, filtered and washed with plenty of ethanol, and dried under vacuum at $50^{\circ} \mathrm{C}$ overnight before characterization. Kinetic curves were obtained by measuring the monomer mass flow with a Brooks flowmeter. Henry's law was used to calculate ethylene concentration from the partial pressure. ${ }^{33}$

\section{Polymer characterization}

${ }^{13} \mathrm{C}$ NMR spectra were obtained from a Varian Mercury 300 FT-NMR spectrometer. Polymers were analyzed in 1,2,4-trichlorobenzene (TCB)/benzene- $\mathrm{d}_{6}$ solution. Evaluation of branching content was calculated according to the literature. ${ }^{34}$ The molecular weights of the polymers were measured by gel permeation chromatography (GPC) using TCB as solvent in a Waters $150 \mathrm{CV}$ plus chromatograph at $135^{\circ} \mathrm{C}$. Polystyrene standards were used for calibration. Thermal analyses were performed on a Perkin Elmer model DSC7 or model 2910 MDSC V4.4E differential scanning calorimeter at a heating rate of $10{ }^{\circ} \mathrm{C} \mathrm{min}^{-1}$. The degree of crystallinity was calculated from the enthalpy of fusion taking the value $293 \mathrm{~J} \mathrm{~g}^{-1}$ for $100 \%$ crystalline polyethylene.

\section{RESULTS AND DISCUSSION}

In this work two Ni diimine complexes containing the pseudohalides isothyocyanate and isoseleniumcyanate as non-chelating ligands were synthesized and tested as pre-catalyst for ethylene polymerization in different reaction condition. The performance of these complexes in catalyzing the polymerization was compared with the analogous complex containing bromide.

\section{Polymerization behavior}

Ethylene polymerization were carried out by using pressures varying from 1 to $3 \mathrm{bar}$, temperature from 0 to $50^{\circ} \mathrm{C}$ and $\mathrm{Al} / \mathrm{Ni}$ molar ratio from 127 to 460 , following an experimental design in which it was taken the temperature of $25^{\circ} \mathrm{C}$ as a central point (triplicate). The results of these tests are presented in Tables 1, 2 and 3.

Both diimine complexes containing pseudo-halide non-chelaging ligands (isothyocyanate, NCS, 1 and isoseleniumcyanate, NCSe, 2) showed significant activity for ethylene polymerization when activated by MAO.

In general terms, the NCS-containing complex exhibited the best activity in all conditions. The polymerization carried out at $50{ }^{\circ} \mathrm{C}$ generated ethylene polymers with pronounced elastomeric behavior, indicating the presence of high content of branches, as expected for polyethylenes prepared with $\mathrm{Ni}$ diimine catalysts with this kind of structure (bulky diimine ligands) at higher temperatures. Based on the data presented in Tables 1, 2 and 3, it is possible to write the following order of activity for the non-chelaging ligands: $\mathrm{NCS}>\mathrm{Br}$ $>$ NCSe. As shown in Table 2 which presents the results of reactions carried out at $25^{\circ} \mathrm{C}$ (central point triplicate), a good reprodutibility of the reaction is attained. The table shows that Complex $\mathbf{2}$ presented the lowest activity, almost $70 \%$ less than Complex $\mathbf{1}$ and $50 \%$ less than Complex 3.

The molecular weights were high (Mw from 703,000 to $1.234 \times 10^{6}$ ) and the molecular weight distributions were relatively broad with polydispersities varying from 3.1 to 3.5. Complex 1 produced polymers with higher $\mathrm{Mw}$ than the other complexes (2 and $\mathbf{3}$ ).

The characteristics of the polymers formed were mainly dependent upon the reaction conditions and structure of the chelating ligand, but also the nature of the non-chelating ligand. After activated by MAO cocatalysts, the real active species in these systems should be a cationic diimine Ni methyl specie. ${ }^{4}$ Therefore, it was expected that the pseudo-halides in the precursors should not influence the polymerization process to a significant extent. However, the MAO anion modified by the interaction with the non-chelating ligand may exert some weakly coordinating ability to the cationic nickel center, exerting therefore some influence over the polymerization. This influence can be explained considering that the active site is an ion pair formed by the metal cation and the counterion made up by MAO and the abstracted non-chelating ligand as illustrated in Figure 2. The type of non-chelaging ligand modifies the interaction of the counterion with the metal center influencing the insertion step and chain walking process to give rise to different degree of branching.

We discuss below the effect of some parameter condition on the polymerization with these catalysts.

\section{Influence of temperature}

For all complexes, the increase in the polymerization temperature increased the catalyst activity. Complex 1 which showed to be the most active catalyst has the best activity at $50{ }^{\circ} \mathrm{C}, \mathrm{Al} / \mathrm{Ni}=280$ and $\mathrm{P}=3$ Bar (Run 28, 5,730 kg PE/mol Ni.h).

When the temperature is increased the molecular weight of the polyethylenes decreased. This decrease of molecular weight with increasing temperature is in accordance with literature reports, and 
Table 1. Polymerization of ethylene with the diimine Ni complexes $\mathbf{1}, 2$ and 3 activated by $\mathrm{MAO}^{\mathrm{a}}$ at $0{ }^{\circ} \mathrm{C}$

\begin{tabular}{|c|c|c|c|c|c|c|c|c|}
\hline Run & Complex & $\mathrm{P}(\mathrm{Bar})$ & $\begin{array}{c}{[\mathrm{Ni}]} \\
\mu \mathrm{mol} \text { per } 100 \mathrm{~mL}\end{array}$ & $\begin{array}{c}\mathrm{Al} / \mathrm{Ni} \\
\text { Molar ratio } \\
\end{array}$ & $\begin{array}{c}\text { Acticity } \\
\text { Kg PE/mol Ni h }\end{array}$ & $\begin{array}{c}\mathrm{Mw} \\
\left(\mathrm{x} 10^{-5}\right)^{\mathrm{b}} \\
\end{array}$ & $\mathrm{Mw} / \mathrm{Mn}$ & $\begin{array}{l}\text { Branch }^{\mathrm{c}} \\
(\mathrm{mol} \%)\end{array}$ \\
\hline 1 & 1 & 1 & 11 & 209 & 2,180 & 12.34 & 3.4 & 8.5 \\
\hline 2 & 2 & 1 & 11 & 209 & 380 & 9.82 & 3.0 & 9.8 \\
\hline 3 & 3 & 1 & 11 & 209 & 483 & 12.10 & ND & ND \\
\hline 4 & 1 & 1 & 5 & 280 & 1,660 & 13.13 & 2.7 & 5.5 \\
\hline 5 & 2 & 1 & 5 & 280 & 470 & $\mathrm{ND}^{\mathrm{d}}$ & ND & 3.4 \\
\hline 6 & 3 & 1 & 5 & 280 & 380 & ND & ND & ND \\
\hline 7 & 1 & 3 & 11 & 127 & 1,260 & 8.87 & 2.6 & 7.9 \\
\hline 8 & 2 & 3 & 11 & 127 & 1,090 & $\mathrm{ND}^{\mathrm{d}}$ & ND & ND \\
\hline 9 & 3 & 3 & 11 & 127 & 560 & $\mathrm{ND}^{d}$ & ND & 8.5 \\
\hline 10 & 1 & 3 & 5 & 460 & 1,553 & 14.04 & 3.2 & 9.1 \\
\hline 11 & 2 & 3 & 5 & 460 & 109 & 11.73 & 3.4 & 8.9 \\
\hline 12 & 3 & 3 & 5 & 460 & 356 & 13.46 & 3.2 & ND \\
\hline
\end{tabular}

${ }^{a}$ Polymerization condition: solvent, toluene $(100 \mathrm{~mL})$; polymerization time, $20 \mathrm{~min}$; reaction temperature $=0{ }^{\circ} \mathrm{C} ; \mathrm{P}=$ monomer pressure; $\mathrm{MAO} / \mathrm{Ni}=100 .{ }^{\mathrm{b}} \mathrm{M}_{\mathrm{n}}$ and $\mathrm{M}_{\mathrm{w}}$ determined by GPC at $135^{\circ} \mathrm{C}$ in $1,2,4$-trichlorobenzene. ${ }^{\mathrm{c}}$ Determined by ${ }^{13} \mathrm{C}$ NMR. ${ }^{\mathrm{d}} \mathrm{Gel}$ formation. $\mathrm{ND}=$ not determined.

Table 2. Polymerization of ethylene with the diimine Ni complexes $\mathbf{1}, \mathbf{2}$ and 3 activated by $\mathrm{MAO}^{\text {a }}$ at $25^{\circ} \mathrm{C}$

\begin{tabular}{lccccc}
\hline Run & Complex & $\begin{array}{c}\text { Acticity } \\
\text { Kg PE per } \\
\text { mol Ni h }\end{array}$ & $\begin{array}{c}\text { Mw } \\
\left(\times 10^{-5}\right)^{\mathrm{b}}\end{array}$ & Mw/Mn & $\begin{array}{c}\text { Branch } \\
(\mathrm{mol} \%)\end{array}$ \\
\hline 13 & 1 & 2,176 & 9.97 & 3.1 & 5.6 \\
14 & 2 & 750 & 12.06 & 3.2 & $\mathrm{ND}$ \\
15 & 3 & 1,456 & 12.10 & 3.4 & $\mathrm{ND}$ \\
16 & 1 & 2,112 & 10.22 & 3.6 & 7.2 \\
17 & 2 & 752 & 10.93 & 3.4 & $\mathrm{ND}$ \\
18 & 3 & 1,337 & 9.29 & 3.2 & $\mathrm{ND}$ \\
19 & 1 & 2,517 & 8.00 & 3.2 & 9.9 \\
20 & 2 & 744 & 11.55 & 3.3 & $\mathrm{ND}$ \\
21 & 3 & 1,371 & 9.39 & 3.1 & $\mathrm{ND}$ \\
\hline
\end{tabular}

${ }^{a}$ Polymerization condition: solvent, toluene $(100 \mathrm{~mL})$; polymerization time, $20 \mathrm{~min}$; polymerization temperature $=25^{\circ} \mathrm{C} ;[\mathrm{Ni}]=8 \mu \mathrm{mol}$ per $100 \mathrm{~mL}$; $\mathrm{Al} / \mathrm{Ni}$ molar ratio $=225$; monomer pressure $\mathrm{P}, 2 \mathrm{Bar} ;{ }^{\mathrm{b}} \mathrm{M}_{\mathrm{n}}$ and $\mathrm{M}_{\mathrm{w}}$ determined by $\mathrm{GPC}$ at $135^{\circ} \mathrm{C}$ in $1,2,4$-trichlorobenzene; ${ }^{\mathrm{c}}$ determined by ${ }^{13} \mathrm{C} \mathrm{NMR}$; $\mathrm{ND}=$ not determined.

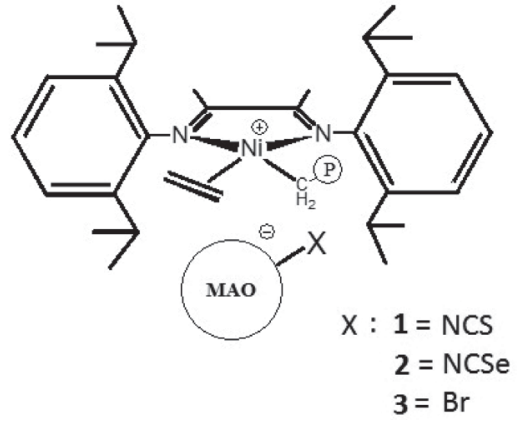

Figure 2. Interaction of the counterion with the complex metal center

can be attributed to increase in chain transfer reactions with the alkylaluminum. ${ }^{34,35}$

At $0^{\circ} \mathrm{C}$, it seems that the molecular weights of the polyethylenes prepared with Complex 2 was slightly lower than those obtained with Complexes 1 and 3. The same behavior was not noted for reactions carried out at 25 and $50^{\circ} \mathrm{C}$. In general terms, at these temperatures, no marked change in the molecular weight was observed in polymerizations using complexes containing NCS and

Table 3. Polymerization of ethylene with the diimine Ni complexes $\mathbf{1}, \mathbf{2}$ and $\mathbf{3}$ activated by $\mathrm{MAO}^{\mathrm{a}}$ at $50^{\circ} \mathrm{C}$

\begin{tabular}{|c|c|c|c|c|c|c|c|c|}
\hline Run & Complex & $\mathrm{P}(\mathrm{Bar})$ & $\begin{array}{c}{[\mathrm{Ni}]} \\
\mu \mathrm{mol} \text { per } 100 \mathrm{~mL} \\
\end{array}$ & $\begin{array}{c}\mathrm{Al} / \mathrm{Ni} \\
\text { Molar ratio } \\
\end{array}$ & $\begin{array}{c}\text { Acticity/ } \\
\text { kg PE per mol Ni h }\end{array}$ & $\begin{array}{c}\mathrm{Mw} \\
\left(\mathrm{x} 10^{-5}\right)^{\mathrm{b}} \\
\end{array}$ & $\mathrm{Mw} / \mathrm{Mn}$ & $\begin{array}{r}\text { Branch }^{\mathrm{c}} \\
(\mathrm{mol} \%)\end{array}$ \\
\hline 22 & 1 & 1 & 11 & 127 & 1,276 & 2.80 & 2.7 & 42.9 \\
\hline 23 & 2 & 1 & 11 & 127 & 334 & 7.14 & 2.8 & 52.3 \\
\hline 24 & 3 & 1 & 11 & 127 & 1,358 & 6.96 & 3.2 & 64.2 \\
\hline 25 & 1 & 3 & 11 & 209 & 2,600 & 7.02 & 3.1 & 22.7 \\
\hline 26 & 2 & 3 & 11 & 209 & 1,260 & 8.06 & 3.4 & 23.5 \\
\hline 27 & 3 & 3 & 11 & 209 & 1,410 & 8.16 & 3.3 & ND \\
\hline 28 & 1 & 3 & 5 & 280 & 5,730 & 7.03 & 3.2 & 30.7 \\
\hline 29 & 2 & 3 & 5 & 280 & 1,090 & 9.84 & 3.1 & ND \\
\hline 30 & 3 & 3 & 5 & 280 & 3,490 & 8.77 & 3.1 & 30.1 \\
\hline 31 & 1 & 1 & 5 & 460 & 3,437 & 6.84 & 3.2 & ND \\
\hline 32 & 2 & 1 & 5 & 460 & 135 & 7.17 & 2.9 & ND \\
\hline 33 & 3 & 1 & 5 & 460 & 1,701 & 7.94 & 3.9 & ND \\
\hline
\end{tabular}

${ }^{a}$ Polymerization condition: solvent, toluene $(100 \mathrm{~mL})$; polymerization time, $20 \mathrm{~min}$; Reaction temperature $=50^{\circ} \mathrm{C} ; \mathrm{P}=$ monomer pressure; $\mathrm{MAO} / \mathrm{Ni}=100 .{ }^{\mathrm{b}} \mathrm{M}_{\mathrm{n}}$ and $\mathrm{M}_{\mathrm{w}}$ determined by GPC at $135^{\circ} \mathrm{C}$ in 1,2,4-trichlorobenzene. ${ }^{\mathrm{c}} \mathrm{M}_{\mathrm{n}}$ and $\mathrm{M}_{\mathrm{w}}$ determined by ${ }^{13} \mathrm{C} \mathrm{NMR}$. ND= not determined. 
$\mathrm{Br}$ non-coordinating ligands at the same condition.

Number of branches increased as the reaction temperature was increased from 0 to $50^{\circ} \mathrm{C}$ (Compare run 1 Table 1 and run 24 Table 3), probably as the effect of increasing intensity of chain walking caused by the temperature.

\section{Influence of $\mathrm{Al} / \mathrm{Ni}$ molar ratio}

When the effect of $\mathrm{Al} / \mathrm{Ni}$ molar ratio is taken into account, it can be observed that small amounts of MAO are enough to efficiently activate the complexes. At $0^{\circ} \mathrm{C}$, complex 1 presented the best activity at $\mathrm{Al} / \mathrm{Ni}$ close to 200, while complex 2 and 3 showed the best activity at around $\mathrm{Al} / \mathrm{Ni} \sim 100$. At this temperature, for all the complexes, increase in $\mathrm{Al} / \mathrm{Ni}$ molar ratio increase $\mathrm{Mw}$. No marked difference was observed in the content of branches in the polymers obtained with the 3 complexes.

Increasing the reaction temperature to $50{ }^{\circ} \mathrm{C}$ made the maximum catalyst activity of Complexes 1 and 3 to be shifted to $\mathrm{Al} / \mathrm{Ni} \sim 200$. In both temperatures $\left(0\right.$ and $\left.50{ }^{\circ} \mathrm{C}\right)$, the 3 complexes showed a decrease in the catalyst activity at $\mathrm{Al} / \mathrm{Ni}$ above 400 , probably due to catalyst deactivation by over reduction of $\mathrm{Ni}^{2+}$ to $\mathrm{Ni}^{0}$. Increase in $\mathrm{Al} / \mathrm{Ni}$ did not change significantly $\mathrm{Mw}$ and $\mathrm{Mw} / \mathrm{Mn}$, but decrease the content of branches in the polymer.

\section{Effect of non-chelating ligands on polymer topology}

The topology of the polyethylenes synthesized with catalysts formed by the complexes containing the non-chelating ligands isothyiocyanates NCS, $\mathbf{1}$ and isoseleniumcyanate, NCSe, $\mathbf{2}$ and MAO at $25^{\circ} \mathrm{C}$ and $\mathrm{Al} / \mathrm{Ni}=100$ was evaluated by ${ }^{13} \mathrm{C} \mathrm{NMR}$. All spectra showed qualitative similar peak patterns as previously reported, ${ }^{28}$ only differing in the relative peak intensities. All the spectra are characteristics of highly branched polyethylenes and, considering the peak patterns, it seems that the non-chelating ligand did not have any marked influence on the topology of the polyethylenes synthesized with these complexes in this condition (See for instance Table 1, Runs 1 and 2; and 10 and 11). It means that the topology is mainly controlled by the diimine chelating ligand. These polymers presented content of branches between 3.4 to $64.2 \mathrm{~mol} \%$ (Tables 1-3). Significant difference was observed, however, in reactions carried out at $50{ }^{\circ} \mathrm{C}$ and $\mathrm{Al} / \mathrm{Ni}=460$ in which the $\mathrm{Br}$ non-chelating ligand was the most effective in forming branches. In that condition all complexes produced very high branched polymers and the following order of capacity in forming branches can be written: $\mathrm{Br}>\mathrm{NCSe}>\mathrm{NCS}$ (See Table 3, run 22, 23 and 24).

\section{Kinetic behavior}

In all polymerizations, ethylene consumption during the reactions was monitored by means of a flowmeter in order to evaluate the kinetic profiles of polymerizations with complexes 1,2 and 3 at different reaction conditions. Effect of reaction temperature on polymerization rate for the catalyst systems of Complexes 1, 2 and $\mathbf{3}$ and MAO are reported in Figures. 3, 4 and 5 as examples. The curves report the kinetic profiles of polymerizations carried out at 0 and $50{ }^{\circ} \mathrm{C}$, range of temperature in which $\mathrm{Ni}$ diimine catalysts usually show maximum performance in olefin polymerization.

The figures show that Complex 1 showed the highest activity in both temperatures. At $0^{\circ} \mathrm{C}$ and $\mathrm{Al} / \mathrm{Ni}$ ratio $=209$ this complex showed polymerization rate which increases with time, reaching a maximum rate of $17.5 \times 10^{-3} \mathrm{~mol} / \mathrm{min}$ at $14 \mathrm{~min}$ (Figure 4 ). At the same condition, Complex 2 is fast activated, reaching it maximum polymerization rate of $7.5 \times 10^{-3} \mathrm{~mol} / \mathrm{min}$ in $6 \mathrm{~min}$, deactivating from this reaction time on. Complex 3 also reached the maximum polymerization rate $\left(5.0 \times 10^{-3} \mathrm{~mol} / \mathrm{min}\right)$ in $6 \mathrm{~min}$, maintaining a constant rate from that time. At this temperature $\left(0^{\circ} \mathrm{C}\right)$, in both condition (Figure 3, $\mathrm{Al} / \mathrm{Ni}=280$ and Figure $4, \mathrm{Al} / \mathrm{Ni}=209)$, the Complex 2 based on NCSe was activated faster than Complex 3 based on $\mathrm{Br}$, but Complex 3 seems to be more stable with time. At the small reaction time of these experiments both Complexes 2 and 3 seems to have the similar performance.

At $50{ }^{\circ} \mathrm{C}$ and $\mathrm{Al} / \mathrm{Ni}=460$ (Figure 5), both Complexes 1 and 3 were quickly activated, reaching the maximum polymerization rate in less than $5 \mathrm{~min}\left(1: 12.4 \times 10^{-3} \mathrm{~mol} / \mathrm{min}\right.$ and $\left.3: 7.3 \times 10^{-3} \mathrm{~mol} / \mathrm{min}\right)$, but showed to be deactivated along the polymerization time. At this temperature, Complex 2 was instable, deactivating progressively.

Considering the kinetic profiles of Figures. 3, 4 and 5, we concluded that, in both temperatures, Complex 1 is quickly activated and presented the highest polymerization rate considering the conditions used in this work. The highest polymerization rate for this catalyst was achieved at $\mathrm{Al} / \mathrm{Ni}=209$ and $0{ }^{\circ} \mathrm{C}$, condition in which it has a polymerization rate 3.4 times higher than the corresponding Br non-chelating ligand (Catalyst 3 ).

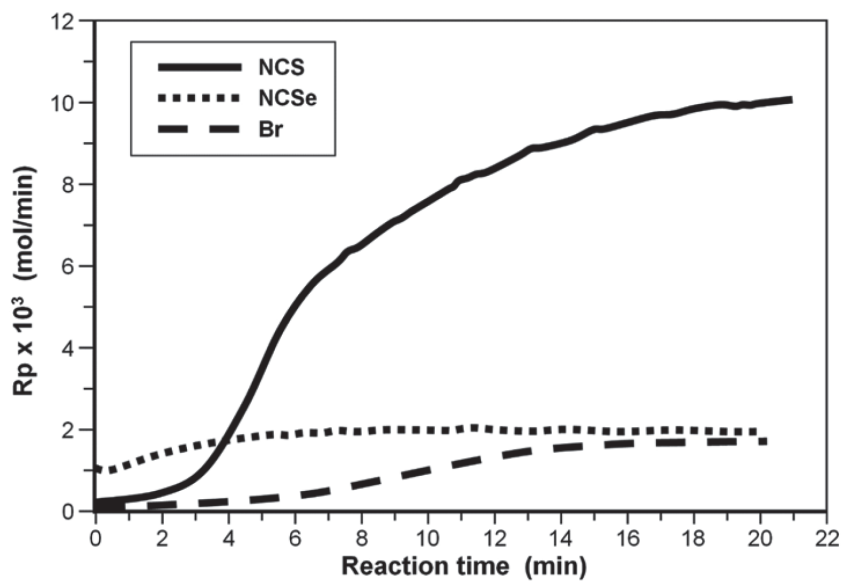

Figure 3. Curves of ethylene consumption for 1, 2 and 3/MAO $(\mathrm{Al} / \mathrm{Ni}=280$, $0^{\circ} \mathrm{C}, \mathrm{P}=1 \mathrm{bar}$ )

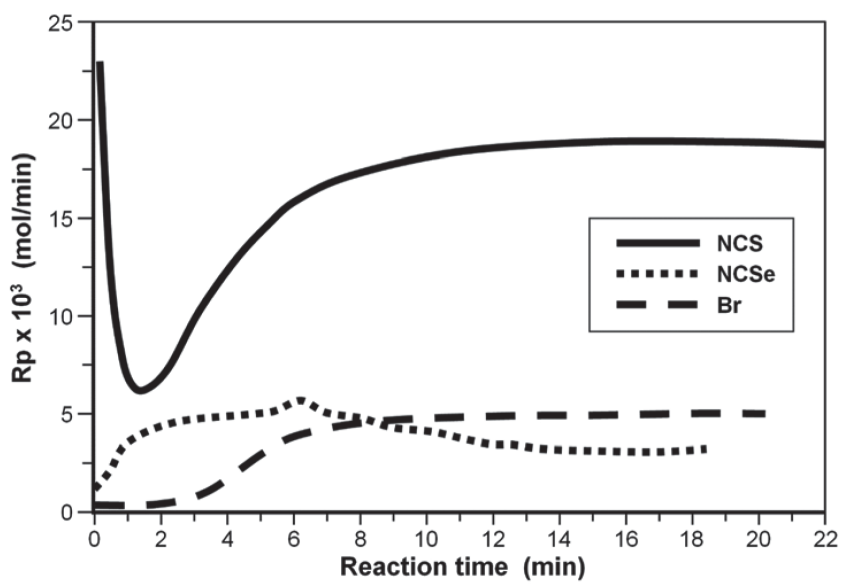

Figure 4. Curves of ethylene consumption for 1,2 and $3 / \mathrm{MAO}(\mathrm{Al} / \mathrm{Ni}=209$, $\left.0^{\circ} \mathrm{C}, \mathrm{P}=1 \mathrm{bar}\right)$

\section{Thermal properties of the polyethylenes}

Some other reactions were carried out in conditions different from those of the experimental design with the more active catalyst system, i.e, that formed by the Complex $\mathbf{1}$ and MAO. The thermal properties of the polyethylenes prepared with this diimine complex containing the pseudo-halide NCS as non-chelating ligands were evaluated by DSC. 


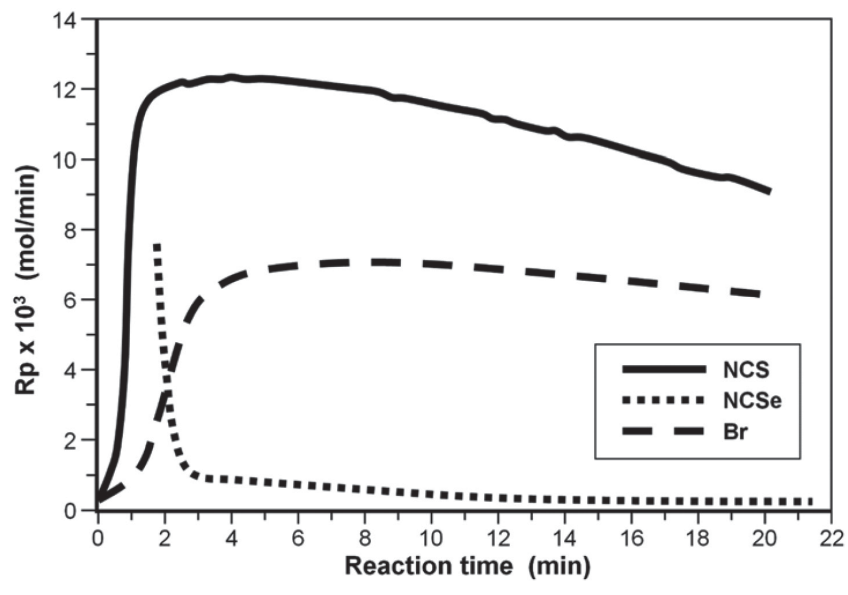

Figure 5. Curves of ethylene consumption for 1,2 and $3 / M A O(A l / N i=460$, $\left.50{ }^{\circ} \mathrm{C}, \mathrm{P}=1 \mathrm{bar}\right)$

Since all ethylene polymers presented elastomeric characteristics, DSC analyses were carried out in temperatures ranging from -120 to $120{ }^{\circ} \mathrm{C}$ in order to determine the $\mathrm{Tg}$ and possible evidence of crystallinity. Table 4 presents the results of these analyses as well as the polymerization conditions employed to obtain the polymers.

The table shows that all the polyethylenes presented a glass transition temperature below $-40{ }^{\circ} \mathrm{C}$, ranging from -40 to $-60{ }^{\circ} \mathrm{C}$, and an endothermic transition above room temperature, except for the sample of run 2, in which the higher transition temperature is not detectable, indicating that this polyethylene is predominately amorphous. The transitions observed at higher temperatures were attributed to the melting ( $\left.\mathrm{T}_{\mathrm{m}}\right)$ of small crystallites formed by small linear ethylene segments.

It is important to note that, the increase in the polymerization temperature decreased the $T_{g}$, probably due to the higher number of branches formed at those higher temperatures. This result is in accordance with the branch content found in runs $4(30.7 \mathrm{~mol} \%)$ and run $1(8.5 \mathrm{~mol} \%)$ shown in Table 1.

\section{CONCLUSIONS}

This work presented data on the ethylene polymerization catalyzed by two Ni diimine precursor containing the pseudo-halides isothiocyanate and isoseleniumcyanate as non-chelating ligand, activated by MAO. Both complexes presented high catalyst activity toward the monomer, producing branched polyethylenes. The kinetic behavior of the polymerizations was dependent upon the structure of the non-chelating ligand and reaction conditions, what could be explained considering that the active site is an ion pair formed by the diamine Ni cation and a counterion made up by MAO and the abstracted multi-atomic non-chelating ligand. The type of nonchelaging ligand modifies the interaction of the counterion with the metal center, influencing mainly the stability of the active site and, consequently, the catalyst activity. The $1 / \mathrm{MAO}$ system proved to be by far the most active system in ethylene polymerization in this work, with polymerization rate even 3 times that of the analogous $\mathrm{Br}$ complex 3 and better performance at $\mathrm{Al} / \mathrm{Ni}$ molar ratio between 200 and 300 .

Table 4. Molecular weight, polydispersity and thermal properties of polyethylenes obtained with the complex $1 / \mathrm{MAO}^{\mathrm{a}}$

\begin{tabular}{lcccccccc}
\hline Run & $\begin{array}{c}{[\mathrm{Ni}]} \\
\mu \text { mol per } 100 \mathrm{~mL}\end{array}$ & $\begin{array}{c}\mathrm{Al} / \mathrm{Ni} \\
\text { ratio }\end{array}$ & $\begin{array}{c}\mathrm{Tp} \\
\left({ }^{\circ} \mathrm{C}\right)\end{array}$ & $\begin{array}{c}\text { Activity } \\
\text { kg PE per mol Ni h }\end{array}$ & $\begin{array}{c}\mathrm{M}_{\mathrm{n}}^{\mathrm{b}} \\
\left(\mathrm{x} 10^{-5}\right)\end{array}$ & $\mathrm{M}_{\mathrm{w}} / \mathrm{M}_{\mathrm{n}}^{\mathrm{b}}$ & $\begin{array}{c}\mathrm{T}_{\mathrm{g}} \\
\left({ }^{\circ} \mathrm{C}\right)\end{array}$ & $\begin{array}{c}\mathrm{T}_{\mathrm{m}} \\
\left({ }^{\circ} \mathrm{C}\right)\end{array}$ \\
\hline 1 & 11 & 209 & 0 & 2,180 & 12.34 & 3.4 & -41.5 & 38.5 \\
2 & 16 & 96 & 25 & 2,080 & 9.85 & 3.2 & -59.6 \\
3 & 11 & 700 & 25 & 1,994 & 8.56 & 3.5 & -46.6 & 99.6 \\
4 & 5 & 280 & 50 & 5,730 & 7.03 & 3.1 & -60.5 \\
\hline
\end{tabular}

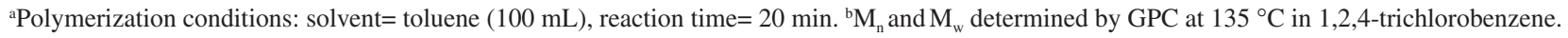

\section{ACKNOWLEDGEMENTS}

The authors thank the Brazilian Agencies CNPq (PADCT, PRONEX and CTPetro), CAPES and FAPERJ (CNE E-26 /201.340/2014) for supporting of this work.

\section{REFERENCES}

1. Johnson, L. K.; Killian, C. M.; Brookhart, M.; J. Am. Chem. Soc. 1995, $117,6414$.

2. Ittel, S. D.; Mecking, S.; Brookhart, M.; Chem. Rev. 2000, 100, 1169.

3. Gibson, V. C.; Spitzmesser, S. K.; Chem. Rev. 2003, 103, 283.

4. Chen, Y.; Wang, L.; Yu, H.; Zhao, Y.; Sun, R.; Jing, G.; Huang, J.; Khalid, H.; Abbasi, N. M.; Akram, M.; Prog. Polym. Sci. 2015, 45, 23.

5. Dai, S.; Sui, X.; Chen, C.; Angew. Chem., Int. Ed. 2015, 54, 9948.

6. Dai, S.; Chen, C.; Angew. Chem., Int. Ed. 2016, 55, 13281.

7. Dai, S.; Zhou, S.; Wen, Z.; Chen C.; Macromolecules 2016, 49, 8855.

8. Zou, W.; Chen, C.; Organometallics 2016, 35, 1794.

9. Na, Y.; Wang, X.; Lian, K.; Zhu, Y.; Li, W.; Luo, Y.; Chen, C.; ChemCatChem 2017, 9, 1062.

10. Wang, R.; Zhao, M.; Chen, C.; Polym. Chem. 2016, 7, 3933.

11. Gates, D. P.; Svejda, S. A.; Oñate, E. C.; Killian, M.; Johnson, L. K.; White, P. S.; Brookhart, M.; Macromolecules 2000, 33, 2320.
12. Daugulis, O.; Brookhart, M.; Organometallics 2002, 21, 5926.

13. Guan, Z.; Marshall, W. J.; Organometallics 2002, 21, 3580.

14. Helldörfer, M.; Backhaus, J.; Alt, H. G.; Inorg. Chim. Acta 2003, 351, 34.

15. Wang R.; Sui X.; Pang W.; Chen C.; ChemCatChem 2016, 8, 434.

16. Dolinsky, M. C. B.; Lin, W. O.; Dias, M. L.; J. Mol. Catal. A: Chem. 2006, 258, 267.

17. Killian, C. M.; McDevitt, J. P.; Mackenzie, P. B.; Moody, L. S.; Ponasik Jr.; J. A.; WO pat. $9840420,1998$.

18. Tomita, T.; Takahama, T.; Sugimoto, M.; Sakaki, S.; Organometallics 2002, 21, 4138 .

19. Cooley, N. A.; Green, S. M.; Wass, P. G.; Organometallics 2001, 20, 4769.

20. Kim, J. S.; Pawlow, J. H.; Wojcinski II, L. M.; Murtuza, S.; Kacker, S.; Sen, A.; J. Am. Chem. Soc. 1998, 120, 1932.

21. Simon, L. C.; Williams, C. P.; Soares, J. B. P.; Souza, R. F.; J. Mol. Catal. A: Chem. 2001, 165, 55.

22. Simon, L. C.; Mauler, R. S.; Souza, R. F.; J. Polym. Sci., Part A: Polym. Chem. 1999, 37, 4656.

23. Moss, G. P.; Smith, P. A. S.; Tavernier, D.; Pure Appl. Chem. 1995, 67, 1307.

24. Harris, J. D.; Eckles, W. E.; Hepp, A. F.; Duraj, S. A.; Fanwick P. E.; Inorg. Chim. Acta 2002, 338, 99. 
25. Ferreira, L. C.; Filgueira, C. A. L.; Visentin, L. C.; Bordinhão, J.; Hörner, M.; Z. Anorg. Allg. Chem. 2009, 635, 1225.

26. S. Chatterjee; Krause, J. A; Liyanage, K. M.; Connick, W. B.; Inorg. Chem. 2012, 51, 4572.

27. Grupp, A.; Bubrin, M.; Ehret, F.; Kvapilová, H.; Záliš, S.; Kaim, W. ; J. Organomet. Chem. 2014, 751, 678.

28. Crossetti, G. L.; Dias, M. L.; Queiroz, B. T.; Silva, L. P.; Ziglio, C. M.; Bomfim, J. A. S.; Filgueiras, C. A. L.; Appl. Organomet. Chem. 2004, $18,331$.

29. Galland, G. B.; Silva, L. P.; Dias, M. L.; Crossetti, G. L.; Ziglio, C. M.; Filgueiras, C. A. L.; J. Polym. Sci., Polym. Chem. 2004, 42, 2171.
30. Dias, M. L.; Silva, L. P.; Crossetti, G. L.; Galland, G. B.; Filgueiras, C. A. L.; Ziglio, C. M.; J. Polym. Sci., Polym. Chem. 2006, 44, 458.

31. Bomfim, J. A. S.; Dias, M. L.; Filgueiras, C. A. L.; Peruch, F.; Deffieux, A.; Catal. Today 2008, 133-135, 879.

32. Pinto, J. C.; Ferreira Jr., L. C.; Melo Jr, P.; Nele, M.; Plastic Research on line, Society of Plastics Engineers 2010, 1.

33. Kissin, Y. V.; J. Polym. Sci., Polym. Chem. 2003, 41, 1745.

34. Galland, G. B.; Souza, R. F.; Mauler, R. S.; Nunes, F. F.; Macromolecules 1999, 32, 1620.

35. Gates, D. P.; Svejda, S. A.; Onate, E.; Killian, C. M.; Johnson, L. K.; White, P. S.; Brookhart, M.; Macromolecules 2000, 33, 2320. 